\title{
Design of bioreactors suitable for plant cell and tissue cultures
}

\author{
Regine Eibl · Dieter Eibl
}

Received: 2 October 2007 / Accepted: 23 November 2007/Published online: 22 December 2007

(C) Springer Science+Business Media B.V. 2007

\begin{abstract}
Plant cell suspension cultures and hairy roots are potential sources of secondary metabolites and recombinant proteins. In contrast to traditionally grown "whole wild plants" or "whole transgenic plants", their production in bioreactors guarantees defined controlled process conditions and therefore minimizes or even prevents variations in product yield and quality, which simplifies process validation and product registration. Moreover, bioreactors and their configuration significantly affect cultivation results by accomplishing and controlling the optimum environment for effective cell growth and production of bioactive substances. This review highlights the main design criteria of the most widely used bioreactor types, both for plant cell suspension cultures and for hairy roots, and outlines suitable low-cost disposable bioreactors which have found increasing acceptance over the last 10 years.
\end{abstract}

Keywords Disposable bioreactors .

Hairy roots · Plant cell suspension cultures .

Plants for human health in the post-genome era, PSE congress 26.8.2007-29.8.2007, Helsinki.

R. Eibl $(\bowtie) \cdot$ D. Eibl

School of Life Sciences and Facility Management, Institute of Biotechnology, Zurich University of Applied Sciences, Campus Grüntal, 8820 Wadenswil, Switzerland e-mail: regine.eibl@zhaw.ch

URL: www.zellkulturtechnik.ch
Secondary metabolites and recombinant proteins . Traditional bioreactors

\section{Introduction}

For more than 45 years plant cell and tissue cultures have been grown in vitro to produce low molecular secondary metabolites. Product examples which are significant in the pharmaceutical industry, the food industry and cosmetics are shikonin, a rich reddishpurple pigment for lipsticks (Kreis et al. 2001), ginsenosides used as food additives and whitening substances (Hibino and Ushiyama 1999; Vanisree et al. 2004), and paclitaxel, a well-known anti-cancer drug (Wink et al. 2005). Their biotechnological production normally results in metabolite productivities between 0.1 and $1 \mathrm{~g}^{-1} \mathrm{~d}^{-1}$, and is successfully realized in large-scale bioreactors.

While plant cell-based secondary metabolite production has a long tradition, recombinant protein expression by growing plant cell and tissue cultures is still in its infancy. To date, about 20-plant made proteins (PMPs) have been produced in proof-ofprinciple studies (Marshall 2006). A landmark success in the manufacturing of plant cell culture based proteins was the first registration of a PMP in February 2006, which was for the vaccine against "Newcastle Disease Virus" (Evans 2006). However, between 2.5- and 25-fold lower protein levels are achieved nowadays if plant cell and tissue cultures 
are used as production organisms instead of the usual mammalian cells (Hellwig et al. 2004; Wurm 2005).

In vitro production of both metabolites and recombinant proteins has mainly been performed by using plant cell cultures and hairy roots. In order to achieve biomass productivities above $1 \mathrm{~g}$ dry weight $\mathrm{1}^{-1} \mathrm{~d}^{-1}$ coupled with moderate metabolite or protein levels, an optimized and well characterized bioreactor is required. Hence studies of the distinctive features of different bioreactor types (such as flow, shear pattern, mixing efficiency and oxygen transfer) are required if mass transfer and shear stress limitations, culminating in low cell growth and product yields, are to be reduced. For example, it is extremely important to monitor shear forces in advance to be able to predict how they will change in relation to cultivation parameters and bioreactor size, and how the design of spargers, impellers and baffles will impact on these forces. Above all, the morphology, rheology, shear tolerance, growth and production behaviour of the culture should be taken into account when choosing the most suitable bioreactor type. Because these most relevant culture characteristics differ for plant cell suspension cultures and hairy roots, we distinguish between bioreactors for these two cell types.

\section{Suitable bioreactors and main design criteria for plant cell suspension cultures}

Stainless steel stirred bioreactors (Fig. 1a), bubble column reactors (Fig. 1b) and airlift reactors (Fig. 1c) directly derived from microbial bioreactors are
Fig. 1 Schematic diagrams of suitable bioreactor types: (a) Stirred bioreactor, (b) Bubble column reactor, (c) Airlift reactor, (d) BioWave reactor, (e) Wave \& Undertow Bioreactor, (f) Slug Bubble Bioreactor, (g) Spray bioreactor, (h) Mist bioreactor, (i) Low Cost Mist Bioreactor (LCMB)

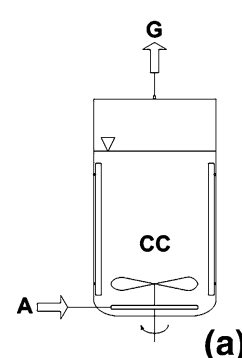

(a)

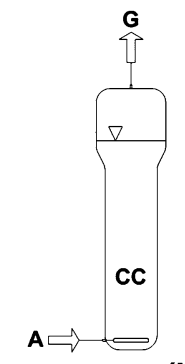

(b)

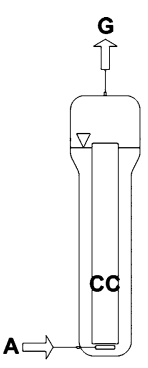

(c)
A - Air inlet

CC - Culture chamber

G - Gas exhaust

H - Harvest

M - Medium

MG - Mist generator

MI - Mist

R - Reservoir

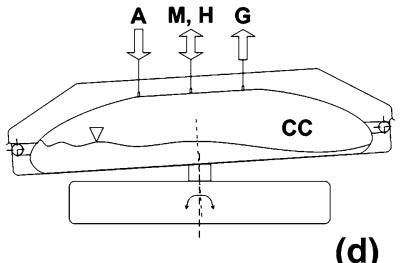

(d)

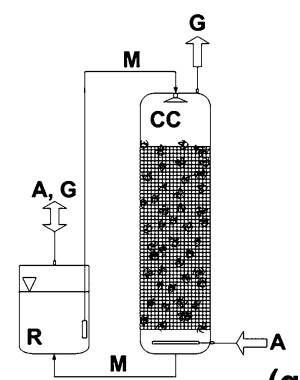

(g)

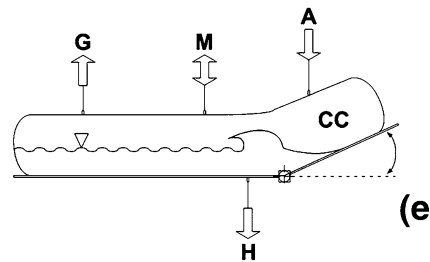

(e)

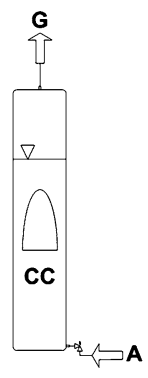

(f)

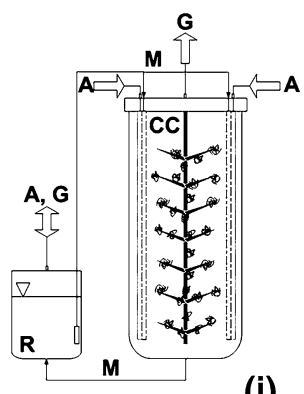

(h)

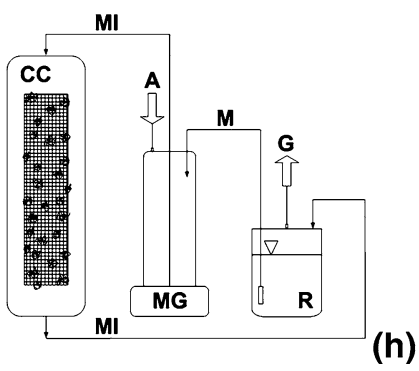


commonly used with only minor modifications to grow plant cell suspension cultures up to $70 \mathrm{~m}^{3}$ culture volume. Engineering analyses demonstrate that serious shear-related effects for plant cells generally arise from the aeration and mixing system, the aeration rate and/or impeller tip speed used.

In most plant cell cultivations the air $(0.1$ and $0.5 \mathrm{vvm})$ is directly introduced via sparger rings positioned in the lower part of the bioreactor. In this way air bubbles are generated which can damage very sensitive plant suspension cells by bubble bursting. A further problem, particularly for directly aerated airlift bioreactors and bubble columns, is extensive foaming resulting from extracellular polysaccharides, fatty acids and high sugar concentrations in the plant cell culture medium. This can cause the dreaded wall growth phenomenon and clogging of the air exhaust filter, both of which constitute a contamination risk. To overcome these disadvantages of sparger rings for plant cells at high aeration rates, ceramic or sintering steel porous spargers, bubblefree aeration via tubes of silicone, external aeration via special devices, oxygen enrichment, changed geometry of the reactor and antifoam agents are recommended (Eibl and Eibl 2002; Su 2006). In the case of aeration in high biomass concentrations exceeding $30 \mathrm{~g}$ dry weight $1^{-1}$, a further disadvantage reported for airlift bioreactors and bubble columns is poor oxygen transfer and heterogeneous biomass distribution. Stirred bioreactors are therefore preferable for culturing plant cell suspensions at high cell densities (Tanaka 2000).

When choosing an impeller system and its pumping mode for stirred bioreactors, the aeration system type and arrangement should be considered. Here, the location of the sparger in the flow direction of the impeller guarantees mass and temperature homogeneity as well as optimal gas dispersion. Until now, impellers considered suitable have included large slow-moving axial flow impellers with low tip speeds of up to a maximum of $2.5 \mathrm{~m} \mathrm{~s}^{-1}$, such as marine impellers or special pitched blade impellers, as well as impellers positioned near the vessel wall, for example spiral stirrers, helical-ribbon impellers and anchor impellers. Radial flow Rushton impellers with concave blades are occasionally used. In addition, alternative impeller systems (e.g. cell-lift impeller, centrifugal-pump impeller) have been installed in stirred vessels (Eibl and Eibl 2002).
The superiority of low-cost and disposable bioreactors possessing a gas-permeable cultivation bag of plastic film was effectively proved in a number of plant cell suspension cultivations. Whereas Osmotek's Life-Reactor and Curtis' Plastic-lined Bioreactor represent pneumatically driven bubble columns, the BioWave (Fig. 1d) investigated by our team was the first mechanically driven bag bioreactor. Today further examples of such bag bioreactors characterized by wave-induced motion (where the mass and energy transfer is manually adjusted via rocking angle, rocking rate, filling level and culture bag geometry) are available, including, the AppliFlex, Tsunami-Bioreactor, Optima and OrbiCell. Rocking their platform induces a wave in the bag, which contains culture medium and cells. While mixing and oxygenation occur, the surface of the medium is continuously renewed and bubble-free surface aeration takes place. Among disposable bag bioreactors with wave-induced motion, the BioWave has a leading position as a result of its scale-up capability to 3001 culture volume and the availability of scale-up criteria based on its hydrodynamic characterization. Moreover, our studies reveal the potential of the BioWave for growing tobacco, grape, apple and yew suspension cells up to 101 culture volume (see Table 1). We achieved maximum biomass productivities of $40 \mathrm{~g}$ fresh weight $\mathrm{l}^{-1} \mathrm{~d}^{-1}$ with excellent doubling times of 2 days. Furthermore, savings in time (no preparation, cleaning and sterilization are required), reduced shearing (indicated by higher viabilities, biomass productivities and no significant change in cell morphology), reduced foaming and a lower risk of contamination were found in the BioWave when compared to cultivations in dominating stirred bioreactors (Eibl and Eibl 2006a, b). The recent disposable bioreactor developments, namely the Wave \& Undertow Bioreactor (Fig. 1e) and the Slug Bubble Bioreactor (Fig. 1f), were successfully used to grow tobacco and soya suspension cells expressing isoflavones up to 1001 culture volume (Terrier et al. 2007).

\section{Suitable bioreactors and main design criteria for hairy roots}

The physiology and morphology of hairy roots demand special consideration with regard to effective 
Table 1 BioWave's results of plant cell and tissue culture cultivations

\begin{tabular}{|c|c|c|c|c|c|c|}
\hline Product & Biocatalyst & CV (1) & Process mode & $\begin{array}{l}\text { Maximum } \\
\text { biomass } \\
\left(\mathrm{g} \text { fw } 1^{-1}\right)\end{array}$ & $\begin{array}{l}\text { Biomass } \\
\text { productivity } \\
\left(\mathrm{g} \mathrm{fw} \mathrm{l}^{-1} \mathrm{~d}^{-1}\right)\end{array}$ & Maximum product yield \\
\hline Taxanes & $\begin{array}{l}\text { T. baccata } \\
\text { suspension } \\
\text { cells }\end{array}$ & 0.4 & $\begin{array}{l}\text { Fed batch }^{\mathrm{a}, \mathrm{d}, \mathrm{f}, \mathrm{g}} \\
\text { Fed batch } \\
\text { a,e,f,g }\end{array}$ & $\begin{array}{l}128 \\
\text { n.a. }\end{array}$ & $\begin{array}{l}\text { n.a. } \\
\text { n.a. }\end{array}$ & $\begin{array}{l}10 \mathrm{mg} \mathrm{l}^{-1} \text { paclitaxel } \\
5 \mathrm{mg} \mathrm{l}^{-1} \text { baccatin III } \\
20.8 \mathrm{mg}^{-1} \text { paclitaxel } \\
7.8 \mathrm{mg}^{-1} \text { baccatin III }\end{array}$ \\
\hline Biomass & $\begin{array}{l}V . \text { vinifera } \\
\text { suspension } \\
\text { cells }\end{array}$ & 1 & Batch $^{\mathrm{b}, \mathrm{d}}$ & 884 & 40 & Metabolic studies \\
\hline Biomass & $\begin{array}{l}\text { M. domestica } \\
\text { suspension } \\
\text { cells }\end{array}$ & 1 & Batch $^{d}$ & 580 & 34.8 & n.a. \\
\hline Biomass & $\begin{array}{l}\text { N. tabacum } \\
\text { suspension } \\
\text { cells }\end{array}$ & 10 & Batch $^{\mathrm{d}}$ & 432 & 22 & n.a. \\
\hline Biomass & $\begin{array}{l}\text { H. procumbens } \\
\text { hairy } \\
\text { roots }\end{array}$ & 1 & Fed batch ${ }^{\mathrm{a}, \mathrm{i}}$ & 154 & 5.6 & Metabolic studies \\
\hline Hyoscyamine & $\begin{array}{l}\text { H. muticus } \\
\text { hairy roots }\end{array}$ & 0.5 & $\begin{array}{l}\text { Fed batch }{ }^{\mathrm{a}, \mathrm{i}} \\
\text { Fed batch }^{\mathrm{a}, \mathrm{c}, \mathrm{i}}\end{array}$ & $\begin{array}{l}596 \\
572\end{array}$ & $\begin{array}{l}21 \\
20.3\end{array}$ & $\begin{array}{l}5.2 \mathrm{mg} \mathrm{g}^{-1} \mathrm{dw} \\
5.0 \mathrm{mg} \mathrm{g}^{-1} \mathrm{dw}\end{array}$ \\
\hline Ginsenosides & $\begin{array}{l}P . \text { ginseng } \\
\text { hairy roots }\end{array}$ & $\begin{array}{l}0.5 \\
0.5 \\
5\end{array}$ & $\begin{array}{l}\text { Fed batch } \\
\text { Fed batch } \\
\text { a,c,h,i }\end{array}$ & $\begin{array}{l}53.3 \\
285 \\
85\end{array}$ & $\begin{array}{l}2.3 \\
5.1 \\
1.4\end{array}$ & $\begin{array}{l}28 \mathrm{mg} \mathrm{g}^{-1} \mathrm{dw} \\
146 \mathrm{mg} \mathrm{g}^{-1} \mathrm{dw} \\
214 \mathrm{mg} \mathrm{g}^{-1} \mathrm{dw}\end{array}$ \\
\hline
\end{tabular}

CV_culture volume; dw_dry weight; fw_fresh weight; n.a.—not available

a feeding during growth phase

${ }^{\mathrm{b}}$ UV-B irradiation

c medium exchange every 14 days

d free cells

e immobilized cells

$\mathrm{f}$ elicitation by methyljasmonate

g additional precursor (mevalonate, $N$-benzoylglycine) feeding

h 52 days

i ebb-and-flow mode

bioreactor design providing a low-shear environment for growing hairy roots and reducing mass transfer limitations (nutrients and oxygen) in densely packed root beds. Root thickness, root length, the number of root hairs and root branching frequency are all affected by numerous factors including the plant species and the Agrobacterium rhizogenes strain used in hairy root induction. These factors, along with nonhomogenous growth and production, complicate the optimization of in vitro cultivation of hairy roots. Indeed, the main problems in bioreactor cultivation of hairy roots result from their tendency to form clumps inherently composed of primary roots and their bridged lateral roots, irrespective of the bioreactor type (Georgiev et al. 2007; Sung and Huang 2006).

Immobilization of hairy roots by horizontal or vertical meshes as well as by cages or polyurethane foam demonstrably promotes their growth in submerged stirred bioreactors, bubble columns, airlift reactors and drum reactors, where the roots are immersed in the culture medium (Eibl and Eibl 2002; Kim et al. 2002; Shadwick and Doran 2004). Furthermore, isolation of the roots from the impeller has become necessary (with only a few exceptions reported) in order to rule out the possibility of root damage even at low tip speeds in stirred bioreactors. 
On the other hand, gas-exchange limitations and insufficient nutrient transport (as a consequence of gentle mixing to lower shear stress) resulting in growth-inhibiting effects have been observed due to the low solubility of gases in the liquid-phase systems listed above (Yu et al. 1997).

The oxygen transfer limitation can be reduced or eliminated by growing hairy roots in gas-phase bioreactors, such as spray or droplet reactors (Fig. 1 g) and mist reactors (Fig. 1h), in which the roots are exposed to humidified air or a gas mixture and nutrients are delivered as droplets by spray nozzles or ultrasonic transducers (Weathers et al. 1999). Another advantage of spray and mist reactors is their low hydrodynamic stress (Towler et al. 2006). However, because of the continuous gas phase in spray and mist reactors, internal root anchor matrices (often horizontal mesh trays and cylindrical stainless steel meshes) are required in all circumstances.

Uniform loading of root matrices in the cultivation chambers is a general problem for hairy root bioreactors. Whereas small-scale bioreactors are manually loaded as open systems in a laminar flow bench or hood, so-called hybrid bioreactors (switching from liquid-phase to gas-phase operation after inoculation, distribution, attachment to the immobilization points, and a short growth phase of the roots) were developed for larger scale. The most cited and largest hybrid bioreactor (bubble column-spray reactor) to grow hairy roots (Datura stramonium) so far is the 5001 Wilson-Bioreactor (Wilson 1997). Yet another means to guarantee simple and safe hairy root inoculation in pilot scale is the integration of a pharmaceutical isolator into the bioreactor concept as realized in the 501 LCMB (Low Cost Mist Bioreactor, Fig. 1i), a mist bioreactor having a cultivation chamber of plastic film (Wink et al. 2005).

Besides the LCMB, further systems with a cultivation chamber of plastic film were tested with hairy roots expressing secondary metabolites or recombinant proteins. Encouraging results, which were achieved in Life-Reactor (Medina-Bolivar and Cramer 2004), Plastic-lined Bioreactor (Shanks and Morgan 1999) and BioWave (Eibl and Eibl 2006a, b, Table 1), allow the conclusion that lowcost disposable reactors may be interesting alternatives for growing hairy roots up to large-scale. However, we believe that the introduction of commercial ginsenoside production by culturing adventitious roots in 10,000 and 20,000 1 balloontype bioreactors from stainless steel in Korea will also encourage the international development of hairy root-based manufacturing processes (Choi et al. 2006).

\section{Conclusions}

For plant cell and tissue cultures, a variety of bioreactor types providing growth and expression of bioactive substances is available today. Most of the plant cell suspension cultures and hairy roots used are grown in submerged stirred bioreactors, bubble columns, airlift reactors and their modifications, gas-phase bioreactors and their combinations, or socalled hybrid systems up to $\mathrm{m}^{3}$-range. Whereas low biomass and product level can be achieved in virtually any of these bioreactor types, an improved understanding of the manifold interactions between cultivated cells, product formation and the specific designs for different bioreactor types will help not only to enhance and sustain high productivity, but also to reduce process costs. The application of scalable low-cost or disposable bioreactors operating with cultivation bags made from plastic film will clearly contribute to additional savings in cost and will exploit the potential of plant cell-based bioprocessing. Disposable stirred bioreactors up to 2,000 1 volume are expected in the near future.

\section{References}

Choi YE, Kim YS, Paek KY (2006) Types and design of bioreactors for hairy root culture. In: Dutta Gupta S, Ibaraki Y (eds) Plant tissue culture engineering, series: focus on biotechnology, vol 6. Springer, Dordrecht, pp 161-171

Eibl R, Eibl D (2002) Bioreactors for plant cell and tissue cultures. In: Oksman-Caldentey KM, Barz WH (eds) Plant biotechnology and transgenic plants. Marcel Dekker, New York, pp 163-199

Eibl R, Eibl D (2006a) Design and use of the Wave Bioreactor for plant cell culture. In: Dutta Gupta S, Ibaraki Y (eds) Plant tissue culture engineering, series: focus on biotechnology, vol 6. Springer, Dordrecht, pp 203-227

Eibl R, Eibl B (2006b) Disposable bioreactors for pharmaceutical research and manufacturing. In: Sovaris S, Toldi $\mathrm{O}$ (eds) Proceedings for 2nd International conference on bioreactor technology in cell, tissue culture and biomedical applications, Saariselkä, Lapland, 27-31 March 2006 
Evans J (2006) Plant-derived drug. http://www.rsc.org/chemistry world/News/2006/February/07020602.asp. Accessed 10 Apr 2007

Georgiev MI, Pavlov AI, Bley T (2007) Hairy root type plant in vitro systems as sources of bioactive substances. Appl Microbiol Biotechnol 74(6):1175-1185

Hellwig S, Drossard J, Twyman RM, Fischer R (2004) Plant cell cultures for the production of recombinant proteins. Nat Biotechnol 22(11):1415-1422

Hibino K, Ushiyama K (1999) Commercial production of ginseng by plant tissue culture technology. In: $\mathrm{Fu} \mathrm{TJ}$, Curtis WR (eds) Plant cell and tissue culture for the production of food ingredients. Kluwer Academic, New York, pp 215-224

Kim Y, Wyslouzil BE, Weathers PJ (2002) Secondary metabolism of hairy root cultures in bioreactors. In Vitro Cell Dev Biol Plant 38:1-10

Kreis W, Baron D, Stoll G (2001) Biotechnologie der Arzneistoffe. Deutscher Apotheker Verlag, Stuttgart

Marshall B (2006) MolecularFarming.com. http://www. molecularfarming.com/PMPs-and-PMIPs.html. Accessed 10 Apr 2007

Medina-Bolivar F, Cramer C (2004) Production of recombinant proteins by hairy roots in plastic sleeve bioreactors. Methods Mol Biol 267:351-363

Shadwick FS, Doran PM (2004) Foreign protein expression using plant cell suspension and hairy root cultures. In: Fischer R, Schillberg S (eds) Molecular farming. WileyVCH, Weinheim, pp 13-36

Shanks JV, Morgan J (1999) Plant hairy root culture. Curr Opin Biotechnol 10(2):151-155

Su WW (2006) Bioreactor engineering for recombinant protein production using plant cell suspension culture. In: Dutta Gupta S, Ibaraki Y (eds) Plant tissue culture engineering, series: focus on biotechnology, vol 6. Springer, Dordrecht, pp 135-159

Sung LS, Huang SY (2006) Lateral root bridging as a strategy to enhance ${ }_{L}$-DOPA production in Stizolobium hassjoo hairy root cultures by using a mesh hindrance mist trickling bioreactor. Biotechnol Bioeng 94(3):441-447

Tanaka H (2000) Technological problems in cultivation of plant cells at high density. Biotechnol Bioeng 67(6):775-790

Terrier B, Courtois D, Hénault N, Cuvier A, Bastin M, Aknin A, Dubreuil J, Pétiard V (2007) Two new disposable bioreactors for plant cell culture: the wave \& undertow bioreactor and the slug bubble bioreactor. Biotechnol Bioeng 96(5):914-923

Towler MJ, Kim Y, Wyslouzil BE, Correll MJ, Weathers PJ (2006) Design, development and applications of mist bioreactors for micropropagation and hairy root culture. In: Dutta Gupta S, Ibaraki Y (eds) Plant tissue culture engineering, series: focus on biotechnology, vol 6 . Springer, Dordrecht, pp 119-134

Vanisree M, Lee CY, Lo SF, Nalawade SM, Lin CY, Tsay HS (2004) Studies on the production of some important secondary metabolites from medicinal plants by plant tissue cultures. Bot Bull Acad Sin 45:1-22

Weathers PJ, Wyslouzil BE, Wobbe KK, Kim YJ, Yigit E (1999) The biological response of hairy roots to $\mathrm{O}_{2}$ levels in bioreactors. In Vitro Cell Dev Biol Plant 35:286-289

Wilson PDG (1997) The pilot-scale cultivation of transformed roots. In: Doran PM (ed) Hairy roots: culture and applications. Harwood Academic, Amsterdam, pp 179-190

Wink M, Alfermann AW, Franke R, Wetterauer B, Distl M, Windhoevel J, Krohn O, Fuss E, Garden H, Mohagheghzadeh A, Wildi E, Ripplinger P (2005) Sustainable production of phytochemicals by plant in vitro cultures: anticancer agents. Plant Gene Res 3(2):90-100

Wurm F (2005) Manufacture of recombinant biopharmaceutical proteins by cultivated mammalian cells in bioreactors. In: Knäblein J (ed) Modern biopharmaceuticals, vol 3 . Wiley VCH, Weinheim, pp 723-759

Yu S, Mahagamasekera MGP, Williams GRC, Kanokwaree K, Doran PM (1997) Oxygen effects in hairy root culture. In: Doran PM (ed) Hairy roots: culture and applications. Harwood Academic, Amsterdam, pp 139-150 